\title{
Migracje słowa Bożego, czyli obrona wartości Wulgaty według Franciszka Titelmansa
}

\author{
Migrations of the Word of God. Francis Titelmans's Defence of the Vulgate \\ TOMASZ KAROL MANTYK \\ Instytut Historii Kościoła i Patrologii, Katolicki Uniwersytet Lubelski Jana Pawła II \\ e-mail: br.tomasz@gmail.com \\ ORCID: 0000-0002-3554-7079
}

\begin{abstract}
A new translation of the New Testament directly from Greek published by Erasmus of Rotterdam in 1516 was a milestone of biblical scholarship. His work, seemingly challenging the traditional Vulgate translation, provoked much opposition. Among Erasmus's adversaries was Francis Titlemans, a young Franciscan theologian from Leuven. In his Prologus Apologeticus he criticised Erasmus's work as a self-aggrandising exercise in vain glory and defended the centuries old authority of the Vulgate. The kernel of his argument was that the word of God migrated from one language to another under strict Divine supervision that ensured its incorruptibility. Thus, biblical translation was not merely a matter of philology but required divine inspiration. Some arguments of Titelmans were reflected in canons of the Council of Trent relating to the Bible. Although the exact content of his arguments appears irrelevant to contemporary Biblical scholarship, some suppositions underlying his polemic with Erasmus sound very similar to those resonating in modern debates, making this 500 years old controversy a valuable subject of study.
\end{abstract}

Keywords: Vulgate, biblical inspiration, translation of the Bible, biblical Humanism, Erasmus of Rotterdam, Francis Titelmans

SŁowa KLuCZE: Wulgata; natchnienie biblijne; tłumaczenie Biblii, Humanizm biblijny, Erazm z Rotterdamu, Franciszek Titelmans

pory o tłumaczenie tekstu Biblii nigdy nie były w chrześcijańskiej teologii

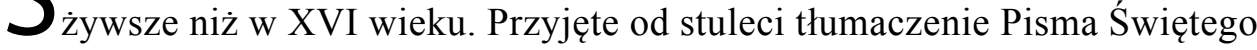
na łacinę, czyli Wulgata, było przedmiotem podwójnej krytyki: po pierwsze ze strony niektórych humanistów, zwłaszcza Erazma z Rotterdamu, po drugie - reformatorów z Marcinem Lutrem na czele. Humaniści, kwestionując scholastyczną metodę uprawiania teologii, zachęcali do powrotu do oryginalnych języków Biblii. Ruchy reformacyjne, kwestionując teologię średniowiecznego Kościoła, wskazywały na błędne tłumaczenie Wulgaty jako jedno ze źródeł jej wypaczeń. Nie brakowało też obrońców tradycyjnego tłumaczenia. Niniejszy artykuł przedstawia apologię Wulgaty pióra szesnastowiecznego franciszkanina i humanisty, Franciszka Titelmansa. Swoją argumentację zawarł 
on w polemicznym dziele Collationes quinque super epistolam ad Romanos, a zwłaszcza w prologu ${ }^{1}$.

Niniejszy artykuł, pisany z perspektywy nauk historycznych i przy użyciu ich metodologii, stawia sobie za cel zrozumienie i zwięzłe przedstawienie istoty sporu o thumaczenie Biblii w początkach XVI wieku. Pośrednio dotyka także ważnych zagadnień z zakresu biblistyki i teologii. Polemika Erazma i Titelmansa podnosiła kwestie: natchnienia biblijnego, a zwłaszcza natchnienia tłumaczeń; autorytatywnego tekstu Pisma Świętego: czy jest nim Wulgata? czy wersje w językach oryginalnych?; prawa do interpretacji Biblii: czy przysługuje tylko teologom? czy również przedstawicielom innych dziedzin nauki?; metodologii interpretacji Pisma: czy prymat należy przyznać narzędziom analizy filologicznej? czy raczej tradycji teologicznej? Co do szczegółów większość z tych zagadnień wydaje się dziś nieaktualna, ponieważ dokumenty Kościoła, zwłaszcza z XX w., jasno dookreśliły rolę metod filologicznych w badaniu Pisma i wyższość autorytetu tekstu greckiego i hebrajskiego nad thumaczeniami. Jednakże badanie owej polemiki sprzed wieków ma znaczenie również dla współczesnej nauki. Po pierwsze ukazuje początki bardziej naukowego podejścia do tekstu biblijnego, pozwalając biblistyce lepiej rozumieć swoje korzenie i pierwotny rozwój. Co więcej, rzuca światło na decyzje Soboru Trydenckiego, które wyznaczyły szlak katolickim badaniom Biblii. Po drugie założenia teologiczne, które towarzyszyły Erazmowi i Titelmansowi, są obecne również w dzisiejszych sporach wokół metody historyczno-krytycznej, stawiając pytanie o miejsce doświadczenia wiary Kościoła w naukowej analizie Pisma.

Istniejąca literatura przedmiotu jest bardzo uboga. W języku polskim nie istnieją żadne opracowania dotyczące sporu Titelmansa z Erazmem²; w literaturze obcojęzycznej jest ono pobieżnie omawiane w pracach Erki Rummel, Roberta Coogana czy Ireny Backhus, jednak jedynymi szerszymi opracowaniami są artykuły Paolo Sartoriego ${ }^{3}$. Ukazuje to, że pomimo olbrzymiego postępu dokonanego w ostatnich latach historyczne badania nad tekstem i interpretacją Biblii

1 F. Titelmans, Collationes quinque super Epistolam ad Romanos beati Pauli Apostoli (Antuerpiae: Apud Guilielmum Vorstermannum 1529).

2 W literaturze polskiej warto zwrócić uwagę na prace poświęcone Erazmowi autorstwa Juliusza Domańskiego, m.in. zbiór esejów: J. Domański, Erasmiana minora. Studia i szkice o pisarstwie filozoficznym i religijnym Erazma z Rotterdamu (Warszawa: Instytut Tomistyczny - Instytut Filologii Klasycznej UW 2017).

3 E. Rummel, Erasmus and his Catholic Critics (Nieuwkoop: Graaf 1989) I-II; Idem (red.), Biblical Humanism and Scholasticism in the Age of Erasmus (Leiden: Brill 2008); R. Coogan, Erasmus, Lee and the Correction of the Vulgate. The Shaking of the Foundations (Genève: Librairie E. Droz 1992); I. Backus, Reformation Readings of the Apocalypse. Geneva, Zurich, and Wittenberg (Oxford: Oxford University Press 2000); P. Sartori, „La Controversia Neotestamentaria Tra Frans Titelmans ed Erasmi da Roterdam (1527-1530 CA.): Liniee di Sviluppo e Contenuti”, Humanistica Lovaniensia 52 (2003) 77-135; P. Sartori, „Tracce dell'opera di Jacobus Latomus nel «Prologus Apologeticus» di Frans Titelmans", Margarita amicorum. Studi di cultura europea per Agostino Sottili (ed. F. Forner - C. M. Monti - P. G. Schmidt) (Milano: Vita \& Pensiero 2005) 1032-1042; P. Sartori, „Frans Titel- 
wciąż pozostają w dużej mierze ziemią nieznaną ${ }^{4}$. Autor wyraża nadzieję, że obecna praca choć w minimalnym stopniu przyczyni się do głębszego poznania dziejów interpretacji Biblii. W artykule zostanie zarysowane tło historyczno-teologiczne powstania tego dzieła, następnie przeanalizuje się argumentację Titelmansa i jego ocenę metodologii humanistycznej, a wreszcie zostanie podjęta próba oceny teologicznej wartości jego pracy.

\section{Kontekst historyczny i teologiczny sporu o tłumaczenie Pisma Świętego}

Spory o poprawność tekstu biblijnego i jego thumaczeń istniały już w starożytności i średniowieczu ${ }^{5}$. Tym, co uczyniło szesnastowieczne dysputy na ten temat szczególnie intensywnymi był nowy kontekst intelektualno-religijny, wypływający z rozwoju humanizmu oraz pojawienia się ruchów reformacyjnych. Postaramy się zwięźle nakreślić to tło, aby wyrażniej ukazać znaczenie prac Franciszka Titelmansa.

\subsection{Humanizm i nowa metodologia interpretacji Biblii}

Podstawowym kontekstem powstania dzieła Titelmansa był humanizm. Narodził się on w północnowłoskich miastach-państwach nie tyle jako nowa filozofia czy teologia, ile nowa metoda badawcza, zwięźle ujęta w motcie ad fontes. Wspólnym mianownikiem dla humanistów było zainteresowanie starożytnymi tekstami i poprawną, klasyczna łacina. Nie był to, wbrew poglądom dawniejszej historiografii, ruch przeciwny chrześcijaństwu czy je kontestujący. Bynajmniej, niemal cały humanizm był głęboko zanurzony w chrześcijaństwie i jej filozofii.

Pierwotnie humaniści zajmowali się jedynie literaturą, jednak z upływem czasu zwrócili swoje narzędzia analizy filologicznej także ku innym dziedzinom, takim jak filozofia, medycyna czy teologia. Pierwszym znanym nam humanistą, który zastosował metodologię humanistyczną do tekstu Biblii był Lorenzo Valla

mans, the Congregation of Montaigu, and Biblical Scholarship", Biblical Humanism and Scholasticism in the Age of Erasmus (ed. E. Rummel) (Leiden: Brill 2008) 215-223.

4 Jednym z owoców badań nad historią Biblii jest czterotomowe dzieło opracowane przez Uniwersytet Cambridge; w kontekście problematyki niniejszego artykułu zob. zwłaszcza: E. Cameron (ed.), The New Cambridge History of the Bible, III, From 1450 to 1750 (Cambridge: Cambridge University Press 2013).

5 Zob. F. A. van Liere, An Introduction to the Medieval Bible (Cambridge: Cambridge University Press 2014) 98-102. 
(1406-1457)6. Potraktował on święty tekst tak samo jak inne, to znaczy uwzględniając specyficzny kontekst historyczny i kulturowy jego powstania. Jego prace zaowocowały nowym tłumaczeniem Nowego Testamentu ze zwięzłym komentarzem (Collatio Novi Testamenti, 1453). Valla przygotował także rozszerzony komentarz, bogatszy o zawartość teologiczną, którego jednak nie opublikował ${ }^{7}$. Jego praca pozostawała szerzej nieznana, dopiero odnaleziona i opublikowana przez Erazma z Rotterdamu w 1505 r., stała się impulsem do dalszych badań humanistów nad tekstem biblijnym.

Lorenzo Valla pozostawał powściągliwy w swoich komentarzach i skupiał się głównie na problemach gramatycznych, unikając kwestii teologicznych ${ }^{8}$. Erazm przeciwnie, żywił dużo większe ambicje teologiczne ${ }^{9}$. Będąc uznanym mistrzem w zakresie klasycznej łaciny i greki, postanowił zwrócić się ku tekstowi biblijnemu. Zamiarem Erazma było oczyszczenie tekstu Pisma Świętego z błędów i przeinaczeń wynikłych z pomyłek skrybów, a także naprawę teologii skrzywionej przez owe błędy. Do zamierzonego zadania zastosował on nowatorską wówczas metodę porównywania tekstu oryginalnych greckich manuskryptów, które udało mu się zgromadzić. Owocem miało być nowe, bardziej poprawne thumaczenie tekstu Nowego Testamentu. Erazm pragnął, aby było ono dostępne dla każdego i stało się kanwą odnowy Kościoła i życia chrześcijańskiego, zgodnie z nakreślonym przez niego w Enchiridion Milites Christiani (1503) programem reformy ${ }^{10}$. Po kilkunastu latach pracy, wspomagany przez przyjaciół, opublikował w 1516 r. Novum Instrumentum. Dzieło zawierało tekst grecki Nowego Testamentu oraz nowe thumaczenie na łacinę przedstawione w równoległych kolumnach. Ponadto tekst opatrzony został obszernym komentarzem filologicz-

6 Zob. M. Fois, Il pensiero cristiano di Lorenzo Valla nel quadro storico-culturale del suo ambiente (Roma: Libreria Editrice dell’Università Gregoriana 1969). Równolegle thumaczenia Nowego Testamentu z greki dokonał Gianozzo Manetti, jednak pozostawało ono w manuskrypcie i nie miało większego wpływu na jemu współczesnych. Zob. E.F. Rice, Saint Jerome in the Renaissance (Baltimore: The Johns Hopkins University Press 1985) 95.

7 J. Monfasani, „Criticism of Biblical Humanists in Quattrocento Italy”, Biblical Humanism and Scholasticism in the Age of Erasmus (ed. E. Rummel) (Leiden: Brill 2008) 21.

8 Zdaniem Monfasaniego („Criticism of Biblical Humanists”, 25-26) było to prawdopodobnie owocem jego wcześniejszych, nieprzyjemnych doświadczeń z inkwizycją w 1444 roku. Jednakże, J. C. Margolin („,The Epistle to the Romans (Chapter 11) according to Versions and/or Commentaries of Valla, Colet, Lefèvre and Erasmus", The Bible in the Sixteenth Century [ed. D. C. Steinmetz] [Durham, NC: Duke University Press 1990] 151) twierdzi, że Valla był równie odważny w swoich komentarzach do tekstu biblijnego jak Erazm.

9 Na temat Novum Instrumentum Erazma zob. J. H. Bentley, Humanists and Holy Writ: New Testament Scholarship in the Renaissance (Princeton, NJ: Princeton University Press 1983) 112-192; C. Augustijn, Erasmus: His Life, Works, and Influence (Toronto: University of Toronto Press 1991) 107-118; C. Christ-von Wedel, Erasmus of Rotterdam: Advocate of a New Christianity (Toronto: University of Toronto Press 2013).

10 A. K. Jenkins - P. Preston, Biblical Scholarship and the Church: A Sixteenth Century Crisis of Authority (Ashgate: Aldershot 2016) 39-48. 
nym i teologicznym. Nie było to pierwsze tego typu przedsięwzięcie. Erazma wyprzedził w tym nie tylko wspomniany Valla, ale także hiszpańscy humaniści, którzy przygotowali wydaną w 1508 r. w Alcali Biblię w językach greckim, hebrajskim i łacińskim, tak zwaną Poliglotę kompluteńską ${ }^{11}$. Jednakże to praca Erazma była przełomowa, gdyż zawierała daleko głębszą treść teologiczną i miała szeroki zasięg oddziaływania - niewątpliwy owoc sławy niderlandzkiego humanisty. Za życia Erazma dzieło doczekało się pięciu wydań i było obiektem licznych polemik i krytyki ${ }^{12}$.

\subsection{Humanizm a reformacja}

Jednym z powodów krytyki Erazma było wiązanie jego osoby z reformacją zapoczątkowaną wystąpieniem Marcina Lutra w 1517 roku. Zarówno humanizm, jak i reformacja nawoływały do odnowy Kościoła (choć rozumiały ją odmiennie); oba nurty chciały też powrotu do oryginalnego tekstu Biblii. Wielu czołowych reformatorów, jak choćby Filip Melanchton, Jan Oekolampadius czy Ulrich von Hutten, było wybitnymi humanistami, którzy wprost odwoływali się do Erazma jako swojego mistrza. W powszechnej świadomości oba ruchy zlewały się w jeden, jak zaświadcza popularne wówczas powiedzenie: „Erazm złożył jajko, a Luter je wysiedział"13. Dopiero z czasem stało się jasne, że nie wszyscy humaniści (w tym sam Erazm) popierają Lutra. Jednak napięcie wygenerowane przez ruchy reformatorskie podniosło atmosferę sporu wokół nowego tłumaczenia Biblii.

\section{3. Życie i twórczość Franciszka Titelmansa}

Franciszek Titelmans był jednym z najlepiej wykształconych krytyków Erazma. Urodził się w 1502 r. w Hasselt (obecna Belgia) ${ }^{14}$. Wcześnie stracił oboje rodziców, ale wspierany przez swego patrona Karola de Carondelet zdobył wykształcenie w Kolegium Montaigu w Lowanium. Ukończył studia w 1521 r. i został nominowany wykładowcą filozofii w jednym z kolegiów uniwersyteckich.

11 Zob. Bentley, Humanists and Holy Writ, 70-110.

12 Przegląd dyskusji wywołanych dziełem Erazma zob. Rummel, Erasmus and his Catholic Critics; Rummel (ed.), Biblical Humanism.

13 E. Rummel, The Confessionalization of Humanism in Reformation Germany (Oxford: Oxford University Press 2000) 18.

14 Wśród biografii Titelmansa zob. np.: A. Paquay, Frans Tittelmans van Hasselt (Franciscus Titelmannus Hassellensis, december 1502-12 september 1537). Opzoekingen over zijn leven, zijne werken en zijne familie (Hasselt: Ceysens 1906); oraz C. de Calmpthout, François Titelmans de Hasselt. ... Esquisse biographique (Bruxelles: Jules de Meester 1903). Zob. też: B. de Troeyer, Bio-bibliographia Franciscana Neerlandica saeculi XVI (Nieuwkoop: B. de Graaf 1969) I. 
W 1523 r. wstąpił do zakonu franciszkanów obserwantów w Lowanium, gdzie od 1526 r. wykładał Pismo Święte i przedmioty filozoficzne ${ }^{15}$. W 1536 r. porzucił świat nauki, udał się do Italii, gdzie wstąpił do nowo zatwierdzonej reformy franciszkańskiej - kapucynów ${ }^{16}$. Po odbyciu nowicjatu, wybrany na przełożonego prowincji rzymskiej, zmarł 12 września 1537 r. osłabiony surowym trybem życia i opieką nad chorymi. Za życia Titelmans ukazało się drukiem kilkanaście jego prac, w tym popularny w XVI w. podręcznik filozofii Arystotelesa ${ }^{17}$.

Swoją formację intelektualną i duchową zawdzięczał zwłaszcza Kolegium Montaigu w Lowanium. Kolegium było częścią kongregacji założonej przez Jana Standoncka, który pragnął zreformować Kościół przez edukację ${ }^{18}$. Standonck był przedstawicielem devotio moderna, a zakładane przez niego kolegia odznaczały się ścisłą dyscypliną, żarliwą pobożnością i wielkim szacunkiem do tradycji. Mimo niewątpliwego konserwatyzmu kolegiów, adepci otrzymywali edukację humanistyczną na wysokim poziomie. Wykładowcą łaciny w Kolegium Montaigu w czasach Titelmansa był Adrian Barlandus, ceniony humanista i wykładowca w Collegium Trilingue Lovaniense ${ }^{19}$. Titelmans otrzymał więc solidne wykształcenie w metodologii humanistycznej, a jednocześnie głębokie ugruntowanie w tradycyjnej teologii.

Członkowie kongregacji Standoncka byli krytyczni wobec Novum Instrumentum Erazma. Przełożony Kolegium Montaigu, Jakub Masson (Jacobus Latomus), był jednym z czołowych krytyków nowego thumaczenia Pisma Świętego. Titelmans pozostawał pod jego wpływem, jednakże nie był tylko - jak oskarżał go Erazm - tubą nagłośnieniową idei Massona ${ }^{20}$, ale rozwinął poglądy swojego nauczyciela, wykazując się znaczną dozą oryginalności. Za pośrednictwem Kolegium Montaigu Titelmans utrzymywał kontakt także z bardzo konserwatywnymi francuskimi krytykami Erazma: Piotrem Cousturierem, przełożonym paryskiej Kartuzji oraz Noëlem Bedą, byłym przełożonym kon-

15 Sartori, „La Controversia Neotestamentaria”, 77.

16 Więcej na temat przejścia Titelmansa do reformy kapucyńskiej zob. M. D’Alatri, „Francesco Tittelmans o del lavoro manuale", Santi e santità nell'Ordine Capucino, I, Il cinque e il Seicento (red. M. D'Alatri) (Roma: Postulazione Generalle dei Cappuccini 1980) 7-19.

17 Na temat dzieł filozoficznych Titelmansa zob. C. B. Schmitt, „The Rise of the Philosophical Textbook", The Cambridge History of Renaissance Philosophy (ed. C. B. Schmitt et al.) (Cambridge: Cambridge University Press 2009), 795-796.

18 Sartori, „Frans Titelmans”, 216. Na temat kongregacji Jana Standoncka zob. M. Godet, La Congrégation de Montaigu (1490-1580) (Paris: Librairie Ancienne Honore Champion 1912); P. J. J. M. Bakker (red.), The College de Montaigu at the University of Paris. Aspects of Its Institutional and Intellectual History (14th-18th Century) (History of Universities 22/2 [Special Issue]; Oxford: Oxford University Press 2008). Na temat J. Standoncka zob. A. Renaudet, Humanisme et Renaissance: Dante, Pétrarque, Standonck, Érasme, Lefèvre d'Étaples, Marguerite de Navarre, Rabelais, Guichardin, Giordano Bruno (Genève: Librairie E. Droz 1958) 114-161.

19 Sartori, „Frans Titelmans”, 219.

20 Zob. Sartori, Tracce dell'opera di Jacobus Latomus, 1033. 
gregacji Standoncka, a później syndykiem Wydziału Teologii Uniwersytetu Paryskiego ${ }^{21}$. Titelmans, jako najmłodszy z tego grona, miał zdecydowanie najlepsze wykształcenie humanistyczne i przedstawił najbardziej oryginalną i rozwiniętą obronę Wulgaty.

\subsection{Zarys przebiegu polemiki Titelmansa z Erazmem}

Titelmans pierwszy raz przedstawił krytykę nowego tłumaczenia Erazma podczas wykładów w studium franciszkańskim w Lowanium, o czym książę humanistów wspomina w jednym ze swoich listów ${ }^{22}$. Erazm próbował uciszyć młodego franciszkanina, pisząc do niego bezpośrednio, ów jednak odrzekł, iż Erazm, często krytyczny wobec innych, nie powinien pozbawiać tego prawa swoich oponentów ${ }^{23}$. Prawdziwa debata rozpoczęła się wraz z publikacją przez Titelmansa dzieła Collationes quinque super epistolam ad Romanos Beati Pauli Apostoli (1529) ${ }^{24}$, w którym podejmuje on dyskusję nad tłumaczeniem Listu do Rzymian - najbardziej istotnego dla reformacji tekstu Nowego Testamentu. Ma ona charakter pięciu fikcyjnych dialogów między młodym uczonym (sam Titelmans) oraz Lorenzo Vallą, Lefèvrem i Erazmem ${ }^{25}$. Krytyka ze strony młodego franciszkanina wywołała gniew Erazma, który nadał mu pogardliwe miano gerontodidascalos (,nauczyciel starszych”). Odpowiedź Erazma została opublikowana jako Responsio ad Collationes cuiusdam iuvenis gerontodidascali $^{26}$. Titelmans odpowiedział na zarzuty w pracy Epistola Apologetica ${ }^{27}$, która nie zawierała jednak nowych argumentów, poza kilkoma uszczypliwościami ad personam.

21 Sartori, „Frans Titelmans”, 218. Na temat polemiki Noela Bedy z Erazmem zob. J. K. Farge, „Noël Beda and the Defense of the Tradition", Biblical Humanism and Scholasticism in the Age of Erasmus (ed. E. Rummel) (Leiden: Brill 2008) 143-164.

22 Zob. D. Erasmus, Opus epistolarum Des. Erasmi Roterdami (ed. P. S. Allen - H. M. Allen) (Oxford: Oxford University Press 1930) VIII, 53.

23 Zob. Erasmus, Opus epistolarum, VIII, 69-70; Sartori, „La Controversia Neotestamentaria”, 81; Rummel, Erasmus and his Catholic Critics, II, 15.

24 Zob. Sartori, „La Controversia Neotestamentaria”, 84.

25 Na temat dzieła biblijnego Lefèvre'a zob. C. Schönau, Jacques Lefèvre d'Etaples und die Reformation (Gütersloh: Gtersloher Verlagshaus 2017). Na temat Lorenzo Valli zob. Fois, Il pensiero cristiano di Lorenzo Valla. Literatura na temat Erazma, zob. wyżej przypis 8.

26 D. Erasmus, „Desiderii Erasmi responsio ad Collationes cuiusdam iuvenis gerontodidascali”, Collected Works of Erasmus, LXXIII, Controversies (red. D. L. Drysdall) (Toronto: University of Toronto Press 1993) 135-263. Zob. też: Sartori, „La Controversia Neotestamentaria”, 85.

27 F. Titelmans, Epistola Apologetica Fratris Francisci Titelmanni Hasselensis pro opere Collationum ad veteris Ecclesiasticae interpretationis Novi Testamenti defensionem aedito, ad Desyderium Erasmum Roterodamum, sacrae Theologiae professorem (Antuerpiae: Guilielme Vorstermannus 1530). 


\section{Koncepcja natchnionych migracji słowa Bożego}

Najważniejszą częścią Collationes Titelmansa jest Prologus apologeticus, w którym autor przedstawia zasadniczą obronę wartości Wulgaty jako tłumaczenia Pisma Świętego. Dlatego też to właśnie prolog będzie podstawowym przedmiotem dalszej analizy. Następujące po prologu pięć dialogów analizuje krok po kroku kontrowersyjne thumaczenia poszczególnych fragmentów Listu do Rzymian. Za każdym razem Titelmans opowiada się za thumaczeniem Wulgaty, odrzucając propozycje swoich adwersarzy ${ }^{28}$.

\subsection{Migracje słowa Bożego}

Dla Titelmansa punktem wyjścia obrony wartości Wulgaty jako thumaczenia Pisma Świętego nie jest filologia, ale teologia. W prologu apologetycznym rozpoczyna on argumentację od wyjaśnienia koncepcji Objawienia. Bóg, według swojego zrządzenia, postanowił objawić się Żydom i uleczyć ich ze ślepoty duchowej, w której pozostawała cała reszta świata ${ }^{29}$. Środkiem Objawienia było prawo nadane Mojżeszowi i spisane w języku hebrajskim. Język nie był tylko środkiem komunikacji, ale także znakiem bliskości Boga ze swoim ludem oraz dowodem wybrania, które domagało się ze strony Żydów wierności przymierzu. Titelmans mocno podkreślał, iż objawienie się Boga Żydom, wybór narodu i języka, nie były przypadkowe, ale wynikały z opatrznościowego zrządzenia Boga ${ }^{30}$.

Objawienie dane Żydom nie było ostateczne. Z jednej strony Bóg pragnął, aby prawda Jego Objawienia była znana ,nie tylko Żydom, ale wszystkim ludom i narodom, zgodnie z objawionymi przepowiedniami proroków"31. Ponieważ język hebrajski ograniczał Objawienie tylko do świata żydowskiego, dlatego konieczne stało się udostępnienie słowa Bożego także w grece i łacinie ${ }^{32}$. Drugim powodem „migracji” słowa Bożego była niewierność narodu wybranego. Zatwardziałość ich serc i odrzucenie słowa zbawienia sprawiły, że prawda Ewan-

28 Niektóre kontrowersje dotyczące szczegółów tłumaczenia omawia J. H. Bentley, „New Testament Scholarship at Louvain in the Early Sixteenth Century", Studies in Medieval and Renaissance History 2 (1979) 72-74.

29 Titelmans, Collationes, fol. a IIr.

30 Titelmans, Collationes, fol. a IIr: „Deus omnipotens [...] populo Hebraeorum [...] pro magno dedit beneficio legis sacrae sanctam scripturam, quam, pro populi electione, Hebraeis voluit hebraico esse semone conscriptam".

31 Titelmans, Collationes, fol. a II ${ }^{\mathrm{r}}$, ,[...] neque iam Iudaeis solis, sed omnibus etiam nationum populis iuxta prophetarum vaticinia revelanda".

32 Titelmans, Collationes, fol. a IIr: ,[...] quae prius apud Hebraeos latitaverant quisque solis proficere potuerant, fact in Graecum sermonem coversione, popoulo gentilium iam fieri inciperent manifesta [...]”. 
gelii została udostępniona poganom, aby ,pierwsi byli ostatnimi, a ostatni pierwszymi”33. Mówiąc o „odejściu” Objawienia od Żydów, Titelmans czyni aluzję do utraty przywileju pierworództwa przez Ezawa na rzecz Jakuba, osadzając pogan w roli Jakuba ${ }^{34}$. Według Titelmansa istnieje ścisły związek między wiernością Bogu i utrzymywaniem czystości wiary a językiem Objawienia:

W ten sposób, gdy zwracamy się ku przewidzianemu zarządzeniu Bożemu, łatwo widzimy: w jaki sposób z poprawnością wiary połączona zawsze była prawdziwość Pism, i z tą poprawnością sama odchodzić zwykła. Jak długo między samymi Żydami utwierdzona była doskonała prawda wiary, między nimi także znajdujemy ukrytą prawdziwość pism"35.

„Migracja” Objawienia z języka hebrajskiego do greckiego, z analogicznych powodów, powtórzyła się następnie z języka greckiego do łacińskiego ${ }^{36}$. Można powiedzieć, że zawartość Objawienia pozostała niezmieniona, ale z łaski Bożej została dwukrotnie przelana $\mathrm{z}$ jednego naczynia do innego ${ }^{37}$. Podobnie jak samo objawienie się Boga Hebrajczykom, tak również dwukrotne tłumaczenie nie było przypadkowe, ale wynikało ściśle ze zbawczego planu Boga, który chce być poznany przez wszystkie narody. Zdaniem Titelmansa tłumaczenie Biblii jest więc czym więcej niż tylko sprawą filologii. Koncepcja „migracji” słowa Bożego z jednego języka do drugiego jest oryginalną myślą Titelmansa i ma kluczowe znaczenie dla zrozumienia jego obrony wartości Wulgaty ${ }^{38}$.

Zarysowawszy ogólną koncepcje roli języków biblijnych w historii zbawienia, Titelmans przechodzi do bardziej szczegółowej analizy dwóch zasadniczych „migracji” słowa Bożego - tłumaczeń na grekę i następnie na łacinę. W odniesieniu do tłumaczenia na grekę Titelmans podąża za historią opowiedzianą w Liście Arysteasza i jej interpretacją przez św. Augustyna ${ }^{39}$. Franciszkanin twierdził, że gdy zbliżała się pełnia czasów, Bóg postanowił wykorzystać dociekliwość króla Ptolemeusza, aby przenieść znajomość swojego Słowa ze świata hebrajskiego do hellenistycznego ${ }^{40}$. Stało się to, dzięki Opatrzności

33 Mt 19,30. Przytoczone dosłownie w Titelmans, Collationes, fol. a III" .

34 Zob. Titelmans, Collationes, fol. a III" .

35 Titelmans, Collationes, fol. a IIIv: „Ita sane dum providam dei dispensationem advertimus, facile videmus: quemadmodum cum fidei rectitudine, connexa semper fuerit scripturae veritas, et cum illa haec velit demigrare sit solita. Donec enim apud solos Iudeos firmitas perstaret rectae fidei, apud eos quoque solos scripturarum veritatem attedimus latitabe". Wszystkie thumaczenia w artykule pochodzą od autora, chyba, że zaznaczono inaczej.

36 Titelmans, Collationes, fol. a IV .

37 Zob. Sartori, „La Controversia Neotestamentaria”, 93.

38 Zob. Sartori, „La Controversia Neotestamentaria”, 93. Według Sartoriego ta idea nie występuje w żadnym innym tekście patrystycznym ani renesansowym.

39 Zob. Sartori, „La Controversia Neotestamentaria”, 97.

40 Zob. Titelmans, Collationes, fol. a IIr. 
Bożej, o czym autor Collationes nie wątpi ${ }^{41}$. Tekst Septuaginty, nie zawierał pełni prawdy, ponieważ Chrystus się jeszcze nie narodził. Stąd boskie Objawienie musiało być dostosowane do ograniczonych możliwości ludzkiego pojmowania. Septuaginta miała być przygotowaniem na przyjście Chrystusa, którego Ewangelia była od początku spisana w grece i zawierała pełnię prawdy ${ }^{42}$. Zdaniem Titelmansa Septuaginta, choć niedoskonała, powinna cieszyć się wielkim szacunkiem, ponieważ jest cytowana przez apostołów w Nowym Testamencie, a także została wykorzystana przez Hieronima przy nanoszeniu poprawek na łacińskie tłumaczenie Starego Testamentu ${ }^{43}$.

To właśnie tłumaczenie na łacinę jest dla Titelmansa najważniejszą „,migracją" słowa Bożego. Przyczyny tej migracji były analogiczne do poprzednich. Po pierwsze Bóg chciał się objawić w świecie łacińskojęzycznym, po drugie Grecy W większej części oddali się marnościom tego świata lub popadli w schizmy oddzielające ich od jedności z Kościołem. Natomiast świat łaciński wydawał się bezpiecznym $\mathrm{i}$ trwałym schronieniem dla prawdy Objawienia ${ }^{44}$. Titelmans podkreśla, że wydarzyło się to ponownie w wyniku działania Bożej Opatrzności i pod natchnieniem Ducha Świętego.

\subsection{Hieronim, vetus interpres i natchnienie tłumaczenia}

Inaczej niż niektórzy krytycy Erazma, Titelmans zdawał sobie sprawę, że Wulgata nie jest wyłącznie dziełem Hieronima ${ }^{45}$. Przyznawał, że przekład pochodzi od anonimowego thumacza, zwanego vetus interpres, którego pracę, vetus editio, Hieronim jedynie przejrzał i poprawi ${ }^{46}$. Mimo że Wulgata nie była wprost dziełem świętego doktora Kościoła, nie traciła nic ze swojej wartości. Titelmans twierdził, że jej autorytatywność płynie od osoby vetus interpres, który był narzędziem woli Bożej i realizował plan objawienia się Boga światu łacińskojęzycz$n^{n e m u}{ }^{47}$. Postać vetus interpres była dobrze znana humanistom i ich krytykom na długo przed Titelmansem, jednak nikt nie przypisywał jej takiej wagi jak lowań-

41 Zob. Titelmans, Collationes, fol. a IIr.

42 Zob. Titelmans, Collationes, fol. a II ${ }^{\mathrm{r}}-\mathrm{a} \mathrm{III}^{\mathrm{v}}$.

43 Zob. Titelmans, Collationes, fol. a VI ${ }^{\mathrm{v}}-\mathrm{a} \mathrm{VII}$.

44 Titelmans, Collationes, fol. a IV ${ }^{\mathrm{r}}$, ,...] graecis ex maxima parte, vel ob innatam levitatem ad vanitates patrias conversis vel ob contentionis studium schismatibus variis ab ecclesiastica unitate divisis, ut simili quoque cura latinis etiam dignam aliquam scripturae stabilitatem concesserit".

45 Na temat sporu o thumacza Wulgaty zob. Rice, Saint Jerome, 173-177. Warto zauważyć, że sama nazwa Wulgata nie była przed Soborem Trydenckim jednoznaczna; zob. Rice, Saint Jerome, 176. W niniejszej pracy termin „Wulgata” jest stosowany zgodnie z terminologią potrydencką.

46 Zob. Titelmans, Collationes, fol. a IV ${ }^{\mathrm{r},}$ także fol. a VIIr.

47 Titelmans, Collationes, fol. d VIIr. 
ski franciszkanin ${ }^{48}$. Według niego ten anonimowy uczony jest wzorem thumacza biblijnego, łączącego w sobie zdolności językowe i głęboką pobożność. Stoi to w opozycji do poglądów Erazma, dla którego vetus editio była przykładem ubogiej stylistycznie łaciny, pełnej barbaryzmów i solecyzmów ${ }^{49}$. Dla Titelmansa nie styl był najważniejszy, ale przeświadczenie, że vetus editio była zamierzona przez Boga, przethumaczona z Jego inspiracji i pod Jego nadzorem. Stąd zasługiwała na najwyższy szacunek, nawet jeśli jej tekst nie odpowiadał gustom językowym humanistów ${ }^{50}$.

Wiara Titelmansa w autorytet Wulgaty była oparta na przekonaniu o Bożym natchnieniu tłumaczenia ${ }^{51}$. Autor Collationes podążał tu za świętymi Hieronimem i Augustynem uznającymi, że także thumaczenie Biblii cieszy się pewną formą natchnienia Bożego. Nie było to takie samo natchnienie, jakim cieszyli się autorzy biblijni, jednak wystarczające, by uchronić thumacza przed popełnieniem błędów w tym, co dotyczy prawd wiary ${ }^{52}$. Oczywiście natchnienie musiało iść w parze z umiejętnościami językowymi tłumacza: głęboką erudycją, doskonałą znajomością greki, łaciny i hebrajskiego oraz obfitymi zasobami leksykalnymi ${ }^{53}$. Titelmans twierdził, że te dary natury były dostateczne do thumaczenia dzieł świeckich, jak choćby w wypadku tłumaczenia Oeconomicus Ksenofonta, dokonanego przez Hieronima ${ }^{54}$. Jednak do przekładu tekstów świętych, nawet tak wybitny filolog jak Hieronim potrzebował nadprzyrodzonej asystencji.

Mówimy więc, że co jest z natchnienia ducha ludzkiego napisane może być ludzkim duchem czytane, ludzkim duchem pojmowane, ludzkim duchem tłumaczone i ludzkim duchem przekładane przez każdego, kto tylko posiada wykształcenie i obfitość słownictwa. I tak Tulliusz aby odpowiednio przełożyć Oeconomicus Ksenofonta nie potrzebował żadnego Ducha Bożego, tym mniej potrzebował go uczony Hieronim, aby odważyć się na coś tego rodzaju. Co prawdziwie z Ducha Bożego jest napisane, aby właściwie było przetłumaczone, widzi się nam, że według Ducha Bożego powinno być czytane, według Ducha Bożego rozumiane i według Ducha Bożego thumaczone ${ }^{55}$.

\footnotetext{
Zob. Sartori, „La Controversia Neotestamentaria”, 108.

Erasmus, „Desiderii Erasmi responsio ad Collationes”.

Zob. Titelmans, Collationes, fol. d VIIr.

Zob. Titelmans, Collationes, fol. $\mathrm{d} \mathrm{I}^{\mathrm{v}}$.

Zob. Titelmans, Collationes, fol. c VIII ${ }^{\mathrm{v}}-\mathrm{d} \mathrm{I}^{\mathrm{r}}$.

Zob. Titelmans, Collationes, fol. $\mathrm{d} \mathrm{I}^{\mathrm{v}}$.

Zob. Titelmans, Collationes, fol. d Iv .

Titelmans, Collationes, fol. d IIr: „Dicamus ergo, quae sunt humano spiritu scripta, spiritu humano legi, spiritu humano intelligi, spiritu humano interpretari, spiritu humano verti posse, ab eo qui eruditionem modo habuerit et verborum copiam. Et sic sane Tullius ad Economicum Xenophontis vertendum nihil opus habebat spiritu divino, neque eo doctissimus Hieronymus, ad eius modi aliquid audendum opus habuisset. Quae vero spiritu divino scripta sunt, ut digna sit interpretatio, sicut spiritu divino legi, sicut spiritu divino intelligi, ita spiritu divino videntur debere interpretari”.
} 
Wiara w boskie natchnienie thumaczenia wynikała wprost $\mathrm{z}$ koncepcji „migracji” słowa Bożego. Bóg nie mógł pozwolić, aby Jego słowo uległo skażeniu, dlatego nieustannie czuwał nad procesem jego przekładu.

Ponieważ dzieło vetus interpres było obdarzone boską asystencją, Hieronim, kiedy otrzymał od papieża polecenie, by poprawić tłumaczenie tekstów Pisma, nie podjął się nowego tłumaczenia, a jedynie oczyścił tekst vetus editio z błędów i przeinaczeń wynikłych z pomyłek kopistów. Titelmans uważał, że z powodu szacunku dla autorytetu vetus editio Hieronim poprawił tylko te fragmenty, w których tekst różnił się znacząco od oryginału ${ }^{56}$. Tam, gdzie znaczenie było jasne, nawet gdy styl pozostawał daleki od ideału, Hieronim nie wprowadził zmian, choć wiemy z cytatów z jego dzieł, że osobiście preferował inne thumaczenie ${ }^{57}$. Dla Titelmansa Hieronim jest tu ideałem pokornego poddania się autorytetowi tekstu przyjętego przez wspólnotę Kościoła. Franciszkanin kontrastował tę postawę z podejściem humanistów, którzy jego zdaniem grzeszyli arogancją, przesadnym uwielbieniem łaciny cycerońskiej oraz pogonią za nowościami ${ }^{58}$.

\section{Franciszka Titelmansa ocena wartości metod humanistycznych}

\subsection{Walory pracy humanistów}

Poglądy Titelmansa nie oznaczają, że był on ,zadeklarowanym wrogiem wykształcenia humanistycznego" 59 . Przyznawał badaniom filologicznym nad tekstem biblijnym pewną wartość, jednak pod warunkiem, że były one podejmowane z uwzględnieniem teologicznego kontekstu, który wcześniej zaprezentował. Autor Collationes miał świadomość, że manuskrypty z tekstem Pisma zawierały błędy i krytyka tekstu polegająca na ich porównywaniu może być pomocna w ustaleniu właściwej wersji tekstu. Jednakże nie zgadzał się z Erazmem, że manuskrypty greckie są co do zasady bardziej wiarygodne niż łacińskie. Nie mogły być, skoro Grecy byli heretykami i schizmatykami i sam Bóg zechciał, aby naczyniem dla Jego objawionego Słowa stała się łacina. Titelmans miał w tym pewną rację, ponieważ Erazm dysponował tylko relatywnie późnymi manuskryptami greckimi pochodzącymi ze średniowiecza, o wiele późniejszymi niż

\footnotetext{
56 Zob. Titelmans, Collationes, fol. a VII ${ }^{\mathrm{v}}$ - a VIIIr.

57 Zob. Titelmans, Collationes, fol. a VIIIr.

58 Por. Sartori, „La Controversia Neotestamentaria”, 112; Rummel, Erasmus and his Catholic Critics, II, 14.

59 Bentley, „New Testament Scholarship at Louvain”, 69.
} 
kodeksy łacińskie znane wówczas na Zachodzie, by nie wspomnieć o źródłach dostępnych Hieronimowi ${ }^{60}$. Wreszcie według Titelmansa filologia miała służyć potrzebom Kościoła, a nie osobistej sławie uczonych. Hieronim dokonał poprawek thumaczenia Biblii na wyraźne polecenie papieża, podczas gdy Erazm i jemu podobni działali z własnej inicjatywy, w pogoni za próżną chwałą.

Niemniej Titelmans dostrzegał pewne walory dzieła Erazma. Był w tym absolutnie wyjątkowy wśród wszystkich krytyków księcia humanistów ${ }^{61}$. Przyznawał, że wiele fragmentów w thumaczenie Erazma, Lefèvre'a i Valli były przydatne „dla pochwycenia pełniejszego zrozumienia"62. Nowe thumaczenia i komentarze w pewnych wypadkach pomagały czytelnikowi lepiej pojąć znaczenie danego fragmentu i stąd mogły być użyteczne do prywatnej, pobożnej lektury ${ }^{63}$. Według Erazma był to dokładnie cel jego wysiłków, jak zaznaczył w przedmowie do Novum Instrumentum ${ }^{64}$. Uczony z Rotterdamu nie uzurpowa1 swemu thumaczeniu roli następcy Wulgaty jako oficjalnego tekstu Kościoła. Jednak Titelmans zdawał się temu nie wierzyć, uznając Erazma za winnego przesady $i$ arogancji ${ }^{65}$.

\subsection{Styl łaciny biblijnej}

„Przesada” to kluczowe słowo dla zrozumienia oceny humanizmu w oczach franciszkanina z Lowanium. Nie uważał on, że prace filologiczne humanistów są zupełnie bezwartościowe, jednakże jego zdaniem byli oni winni przekraczania granic swoich kompetencji. „Przykładali sierp do nie swojego żniwa”, by użyć popularnego w XVI w. przysłowia ${ }^{66}$. Innymi słowy, choć byli oni biegli w filologii, nie powinni byli zajmować się teologią. Jeżeli rzeczywiście tekst biblijny wymagał korekt, zauważał Titelmans, wystarczyło go poprawić, a nie przygotowywać całkiem nowe thumaczenia i to wraz z komentarzem o charakterze ściśle teologicznym. Nie dość, że było to przejawem przesady i arogancji, to jeszcze stwarzało poważne zagrożenie dla autorytetu Kościoła i tekstu Pisma Świętego ${ }^{67}$. Jeżeli tekst biblijny był skażony, to dogmaty Kościoła były oparte na błędnym tekście. Zresztą sama Biblia przestawała być wiarygodna, skoro każdy

60 Szczegółową dyskusję nad źródłami dostępnymi dla Erazma zob.: E. Rummel, Erasmus' Annotations on the New Testament. From Philologist to Theologian (Toronto: University of Toronto Press 1986) 35-42.

61 Por. Sartori, „La Controversia Neotestamentaria”, 119.

62 Titelmans, Collationes, fol. $7^{\mathrm{v}}$ : ,,ad pleniorem intelligentiam capiendam”.

63 Titelmans, Collationes, fol. c $7^{\mathrm{v}}$.

64 Zob. Jenkins - Preston, Biblical Scholarship and the Church, 42-43.

65 Sartori, „La Controversia Neotestamentaria”, 120.

66 Zob. Rummel, The Confessionalization of Humanism, 11.

67 Zob. Titelmans, Collationes, fol. a IV ${ }^{\mathrm{r}-\mathrm{v}}$. 
mógł ją tłumaczyć według własnego uznania. W obu tych zarzutach pobrzmiewa wyraźnie echo reformacji. Wszakże Luter, aby potwierdzić swoje koncepcje teologiczne, przygotował nowe tłumaczenie Pisma Świętego na język niemiecki, i to w oparciu o Novum Instrumentum Erazma ${ }^{68}$. Wreszcie franciszkański uczony obawiał się, że nowe thumaczenie otworzy puszkę Pandory nowych i starych herezji. Według niego fragmenty, które od wieków stanowiły pożyteczny zestaw argumentów do obalania heretyckich tez, stają się w nowym tłumaczeniu zupełnie bezużyteczne ${ }^{69}$. Titelmans odwoływał się do przykładu słynnego Comma Iohanneum, twierdząc, że jego pominięcie otworzy przestrzeń dla nowych Arian $\mathrm{i}$ innych, dawno już pokonanych heretyków ${ }^{70}$.

Przesada była pogwałceniem złotej zasady nauki wyznawanej przez Titelmansa: ne quid nimis. Zapożyczył on upodobanie do umiaru od swojego mentora, Jakuba Massona, według którego zadaniem nauczyciela było pobudzać u ucznia umiłowanie równowagi i powściągać młodzieńcze tendencje do przesady i wyolbrzymieńn $^{71}$. Zasada umiaru wypływała wprost $\mathrm{z}$ duchowości devotio moderna praktykowanej w Kolegium Montaigu, w którym uformowali się obaj - Masson i Titelmans. Podkreślała ona pokorę, szacunek do tradycji i świadomość własnych ograniczeń intelektualnych ${ }^{72}$.

Ne quid nimis miała być naczelną zasadą stylistyczną przy thumaczeniu Biblii. Według Titelmansa styl vetus interpres był swoistą drogą środka pomiędzy dwoma innymi typami, które przedstawia, omawiając teorię stylów łacińskich:

Istnieje elokwencja cielesna, delikatna i pochlebcza, słodka i zniewieściała, zrodzona z cielesnych lędźwi raczej niż z Bożego Ducha. Ta najbardziej podoba się zniewieściałym i cielesnym mężczyznom. Jest też inny rodzaj elokwencji, nie lepszy od pierwszego, lecz wzniosły, wyrafinowany, podniosły, ważący słowa w sposób zachwycający, dobierający frazy i ozdabiający je na sposób po ludzku cudowny. Mędrcy tego świata wyrażają w tym stylu swą cudowną mądrość w sposób tak skomplikowany, że pozostaje zrozumiałą tylko dla najmniejszej grupki czytelników. To jest znajomość litery - wyjątkowy styl, w którym mędrcy w zdumiewający sposób prezentują swe doktryny światu - która usuwa pokorę Chrystusowego Krzyża. Paweł był dumny, że ten właśnie styl odrzucał, pogardzając nim i pozostawiając go książętom tego

68 Na temat thumaczenia Lutra zob. J. L. Flood, „Martin Luther's Bible Translation in its German and European Context", The Bible in the Renaissance. Essays on Biblical Commentary and Translation in the Fifteenth and Sixteenth Centuries (ed. R. Griffiths) (Aldershot: Ashgate 2001).

69 Zob. Rummel, Erasmus and his Catholic Critics, II, 17.

70 Na temat Comma Iohanneum zob. G. McDonald, Biblical Criticism in Early Modern Europe. Erasmus, the Johannine Comma, and Trinitarian Debate (Cambridge: Cambridge University Press 2016). Na temat rzeczywistego wpływu Erazma na szesnastowiecznych antytrynitarzy zob. P. G. Bietenholz, Encounters with a Radical Erasmus. Erasmus' Work as a Source of Radical Thought in Early Modern Europe (Toronto: University of Toronto Press 2009) 33-67.

71 Sartori, Tracce dell'opera di Jacobus Latomus, 1041.

72 Sartori, „Frans Titelmans”, 216. 
świata. Ten rodzaj jest w znacznym stopniu bardziej męski niż pierwszy, bardziej dojrzały, a także od tamtego bardziej dumny i dostojny. [...] Gdy przedwieczna mądrość Ojca przyszła na ten świat, nie wybrała żadnego z tych stylów. Jako nowy filozof, wręcz nowy mędrzec i nowy nauczyciel, ukazał On tym, którzy uwierzyli w Niego trzeci rodzaj elokwencji. Jest to styl czysty i posty, pokorny i skromny, łagodny i dobry, ścisły i zadowalający, przejrzysty i jasny rodzaj elokwencji, w jakim przemawiał On do nas w ciele ludzkim i w jakim chce, aby przemawiali Jego uczniowie ${ }^{73}$.

Style krytykowane przez Titelmansa były typowe dla humanizmu i odnosiły się odpowiednio do poezji i retoryki. Jego zdaniem trzeci styl górował nad nimi nie dlatego, że podobał się uczonym, lecz ponieważ był natchniony przez Boga. Nie znaczy to, że autor Collationes całkowicie odrzucał światowe style łaciny. Były one pożyteczne w odniesieniu do dzieł świeckich. Titelmans dążył do przewartościowania humanistycznej hierarchii stylów, w której łacina cycerońska uchodziła za ostateczny ideał i punkt odniesienia. Nie negując piękna łaciny Marka Tulliusza chciał on dowartościować „styl pobożny” jako doskonalszy w tym, co odnosiło się do wiary. Titelmans ośmieszał współczesną sobie modę, zgodnie z którą wszystko, czego nie można było znaleźć u Cycerona, było złą łaciną i barbaryzmem. Twierdził, że istnieją także inne wzorce dobrej łaciny, jak choćby Ojcowie Kościoła z Hieronimem na czele. Ich styl, choć różny od Cycerona, był na swój sposób elegancki i klarowny ${ }^{74}$. Gdyby było inaczej, twierdził Titelmans, należałoby winą za rzekomo niedoskonałą łacinę Wulgaty obciążyć samego Ducha Świętego, który przecież nadzorował thumaczenie ${ }^{75}$. Wzniosły styl humanistów był więc użyteczny, gdy chodziło o sprawy świeckie, jednak w tym, co boskie, należało pokornie zaakceptować prosty i pobożny styl, jaki znajdujemy w Wulgacie.

73 Titelmans, Collationes, fol. d IV ${ }^{\mathrm{r} v \mathrm{v}}$ : „Est enim carnalis quaedam eloquentia, blandiloqua et assentatoria, mollis atque foeminea: quae ex lumbis potius carnis, $\mathrm{q}[\mathrm{uam}]$ ex spiritu dei, ortum habet, et carnales homines atque muliebres viros plurimum oblectat. Est alia eloquentia non aeque ut prior venerea, sed magnifica, sublimis, et grandiloqua, mira maiestate verba trutinans, orationes librans, miris ad ornata humanis affectibus. Qua sermonis forma usi sunt sapientes huius saeculi, ad suam admirabilem sapientiam sic obscure describendam, ut quae paucissimis esset accessibilis. Haec est illa verbi sapientia atque sermonis supereminentia, in qua sapientes mundo sua dogmata magnifice tradunt, quae crucis Christi himilitatem evacuat, quam se Paulus nescire gloriatur, quam ipse despiciens, huius saeculi princibus relinquit. Est autem haec, priori aliquanto magis mascula, magisque virilis, atque eo quidem superbior et supereminentior [...]. Verum aeterna patris sapientia veniens in mundum, nec hanc nec illam elegit: sed tertiam quandam novus philosophus, immo vero novus sophus et novus magister nobis demonstavit credendibus in eum. Haec est simplex illa et casta, humilis et modesta, mitis et benigna, severa et amabilis, munda et nitida eloquentia, qua et ipse est in carnae nobiscum locutus, et suos item discipulos loqui voluit".

74 Titelmans, Collationes, fol. $\mathrm{d} \mathrm{V}^{\mathrm{v}}-\mathrm{d} \mathrm{VI}$.

75 Titelmans, Collationes, fol. d VIII ${ }^{\mathrm{v}}-\mathrm{e} \mathrm{I}^{\mathrm{r}}$. 


\subsection{Wnioski}

Dyskusja na temat stylu łaciny ukazuje istotę różnicy między Titelmansem i Erazmem. Był nią punkt wyjścia, podstawowe założenie, jakie warunkowało ich podejście do tłumaczenia tekstu Biblii. Według Erazma filologia miała kierować teologią. Autora Collationes, przeciwnie, uznawał prymat dogmatów Kościoła nad osiągnięciami filologii i choć dostrzegał walory tej ostatniej jako ancilla theologiae, to nie mógł przystać na to, by odkrycia filologiczne kwestionowały dogmaty wiary.

W pewnym sensie Erazm i Titelmans byli sobie bliżsi niż sami to dostrzegali. Paolo Sartori słusznie zauważył, iż ,na ironię, Titelmans był w pewnym sensie Erazmianinem: studiował trzy języki biblijne i przyjmował metodę filologiczną proponowaną przez Erazma"76. Ze swoją znajomością języków biblijnych i umiejętnością sięgania do źródeł Titelmans był wcieleniem modelu humanisty, jaki Erazm zalecał. Tym, co stało pomiędzy nimi, była reformacja.

Erazm rozpoczynał swoją pracę nad tekstem Biblii na wiele lat przed wystąpieniem Lutra. Dla niego krytyka tekstu biblijnego była kwestią akademicką, której można było oddawać się w zaciszu gabinetu. Żywił nadzieję, że doskonalej przetłumaczony tekst Pisma stanie się pomocą w moralnej odnowie Kościoła. Titelmans widział jednak w nowych thumaczeniach Biblii palący problem teologiczny, od którego rozwiązania zależało bezpośrednio zbawienie wielu, wszakże tłumaczenie Nowego Testamentu, którego dokonał Marcin Luter, było oparte na Novum Instrumentum Erazma. Kwestia jednego przecinka, zaimka lub czasownika nie była dla Titelmansa zagadnieniem czysto filologicznym, ale potencjalną herezją zagrażającą Kościołowi. W Epistola Apologetica, opublikowanym w odpowiedzi na atak Erazma na Collationes, franciszkanin zarzucał wielkiemu humaniście, iż zdeprawował wielu młodych ludzi, którzy, jak von Hutten, Melanchton czy Oekolampadius, stali się ,wodzami i liderami heretyków”77. Dlatego też Erazm, choć sam nie stanął po stronie reformatorów, był zdaniem Titelmansa winnym wydarzeń minionej dekady.

\section{Spór o tłumaczenie Wulgaty a Sobór Trydencki}

Szesnaście lat po publikacji Collationes kwestie autorytetu Wulgaty weszły do agendy Soboru Trydenckiego. Na tym etapie badań nie potrafimy stwierdzić, czy dzieło Titelmansa miało bezpośredni wpływ na przebieg debat podczas so-

76 Sartori, „Frans Titelmans”, 220.

77 Zob. Rummel, Erasmus and his Catholic Critics, II, 20. 
boru, niewątpliwie jednak, wpisywało się w ogólną dyskusję nad tłumaczeniem Pisma Świętego. Argumentacja lowańskiego teologa znalazła tylko częściowe odzwierciedlenie w postanowieniach Soboru Trydenckiego, który uznał Wulgatę za autentyczne tłumaczenie Pisma Świętego. W Dekrecie o wydaniu i korzystaniu z Ksiąg Świętych przyjętym 8 kwietnia 1546 r. podczas IV sesji soboru czytamy:

Ponadto święty synod, biorąc pod uwagę, że może być nader korzystnym dla Kościoła Bożego, jeżeli któreś spośród wszystkich wydan łacińskich obejmujących święte Księgi będzie uważane za autentyczne, postanawia i wyjaśnia, aby to stare i powszechnie uznane wydanie, które będąc w użyciu przez tyle stuleci zdobyło sobie uznanie w Kościele, było traktowane jako autentyczne w nauczaniu publicznym, $w$ dysputach, kazaniach $\mathrm{i}$ wykładach, a także by nikt nie ważył się ani nie ośmielał, pod żadnym pozorem, go odrzucaćc ${ }^{78}$.

Nie znaczy to jednak, że sobór odrzucał inne tłumaczenia ${ }^{79}$. Jak w dyskusji nad dekretem zauważył Piotr Bertano, biskup Fano, także w starożytności istniały różne thumaczenia, również te dokonane przez heretyków, a jednak Kościół ich nie odrzucał. Inne tłumaczenia mogą pomóc w doskonalszym rozumieniu treści Pisma. Potrzeba było jednak jasnego określenia autentyczności Wulgaty w celu uniknięcia możliwego zamieszania wśród wiernych. Tym samym stanowisko soboru pokrywało się całkowicie z tym, które prezentował Titelmans.

Również w kwestii indywidualnej interpretacji Pisma sobór zajął podobne jak lowański teolog stanowisko:

Oprócz tego dla poskromienia lekkomyślności myślenia sobór postanawia, aby nikt w oparciu o własne sądy dotyczące wiary i moralności, należące do gmachu nauki chrześcijańskiej, nie dostosowywał Pisma Świętego do swoich opinii, wbrew rozumieniu, które utrzymywała i utrzymuje święta Matka Kościół ${ }^{80}$.

78 Dekret Recipitur vulgata editio bibliae praescribiturque modus interpertandi sacram scripturam IV sesji Soboru Trydenckiego: „Insuper eadem sacrosancta synodus considerans, non parum utilitatis accedere posse ecclesiæ Dei, si ex omnibus Latinis editionibus, quæ circumferuntur, sacrorum librorum, quænam pro authentica habenda sit, innotescat; statuit et declarat, ut hæc ipsa vetus et vulgata editio, quæ longo tot sæculorum usu in ipsa ecclesia probata est, in publicis lectionibus, disputationibus, prædicationibus et expositionibus pro authentica habeatur; et ut nemo illam rejicere quovis prætextu audeat vel præsumat". Tekst i thumaczenie za: A. Baron - H. Pietras (red.), Dokumenty Soborów Powszechnych. Tekst łaciński i polski (Kraków: Wydawnictwo WAM 2007) IV/1, 212-213.

79 Zob. J. W. O’Malley, Trydent. Co się zdarzyto podczas soboru (Kraków: Wydawnictwo WAM 2014) 109.

80 Dekret Recipitur vulgata editio bibliae praescribiturque modus interpertandi sacram scripturam IV sesji Soboru Trydenckiego: „Præterea, ad coercenda petulantia ingenia, decernit, ut nemo, suæ prudentiæ innixus, in rebus fidei, et morum ad ædificationem doctrinæ christianæ pertinentium, sacram scripturam ad suos sensus contorquens, contra eum sensum, quem tenuit et tenet sancta 
Oczywiście zapis ten skierowany był przede wszystkim przeciw protestantom, jednakże w poskromieniu „lekkomyślności” tych, którzy dostosowują Pismo Święte do swoich opinii Titelmans widziałby z pewnością także Erazma i jemu podobnych.

$\mathrm{W}$ dokumentach soborowych brak potwierdzenia centralnej $\mathrm{w}$ argumentacji Titelmansa nauki o natchnieniu tłumaczenia Wulgaty i migracjach słowa Bożego. Wspomniany dekret z 8 kwietnia 1546 r., mówiąc o autentyczności Wulgaty, podkreśla, że owo tłumaczenie zdobyło sobie uznanie przez wielowiekowe używanie w Kościele, ale nie wspomina nic o Bożym natchnieniu tłumaczenia Wulgaty. Współczesne dokumenty Kościoła jasno wskazują na to, iż tłumaczenie jest kwestią kompetencji filologicznych thumacza, natomiast tekstem natchnionym w pełnym tego słowa znaczeniu jest tylko oryginał.

[Egzegeta] ma sumiennie przykładać się do coraz większej znajomości języków biblijnych oraz innych wschodnich, aby swój wykład biblijny poprzeć wszelkimi środkami pomocniczymi, które podają rożne gałęzie filologii. [...] Według tych samych zasad trzeba teksty pierwotne thumaczyć. Pochodząc od samego pisarza natchnionego, mają one wyższy autorytet i większą uwagę aniżeli nawet najlepsze tłumaczenie dawnych czy nowych czasów ${ }^{81}$.

Oczywiście wierne thumaczenie uczestniczy w biblijnym natchnieniu, jednak sama praca tłumacza nie podlega charyzmatowi natchnienia.

\section{Zakończenie}

Podsumowując, Franciszek Titelmans bronił wartości Wulgaty opierając się na tradycji i argumentach natury teologicznej. Nie wynikało to z jego pogardy do filologicznych metod humanizmu, które sam znał i z których korzystał, ale z założeń natury teologicznej. Według Titelmansa prawda Pisma Świętego opiera się na autorytecie Kościoła i żywym działaniu Ducha Świętego w tymże Kościele. Franciszkanin widział to działanie w natchnieniu tłumaczenia biblijnego i opatrznościowych „,migracjach” słowa Bożego, które miały uchronić prawdę tekstu od błędów. Obie koncepcje, a zwłaszcza druga, są przejawem oryginalnej myśli teologicznej Titelmansa. Żadna z tych idei nie została przyjęta przez Kościół jako prawda wiary i mają one znaczenie tylko historyczne. Podobnie od dawna nikt już nie wysuwa obiekcji względem metod filologicznych stosowa-

mater ecclesia". Tekst i thumaczenie za: Baron - Pietras (red.), Dokumenty Soborów Powszechnych, s. 213.

81 Pius XII, „Encyklika Divino Afflante Spiritu”, Nowy Testament na tle epoki (red. E. Dąbrowski) (Poznań: Pallottinum 1958) II, 413. 
nych przez Erazma, takich jak porównywanie manuskryptów i próby docierania do tekstu oryginalnego. Nie znaczy to jednak, że dzieło Titelmansa nie ma żadnego znaczenia dla współczesności. $Z$ perspektywy historyka jest ono cennym źródłem poznania klimatu intelektualnego poprzedzającego Sobór Trydencki. Pozwala lepiej umiejscowić w szerokim kontekście intelektualnym epoki toczone na nim debaty, a także rzuca światło na późniejszy rozwój katolickiej biblistyki. Temat ten wymaga z pewnością dalszych badań historycznych. Z perspektywy teologa trzeba stwierdzić, że choć co do szczegółów argumenty Titelmansa już od dawna nie są relewantne, to jednak podstawowa prawda, której bronił, jest dziś równie aktualna jak w dobie renesansu ${ }^{82}$. Otóż Słowo Boże ma swoją ojczyznę. Nie jest nią łacina Wulgaty, lecz wspólnota Kościoła. Jak napisał papież Benedykt XVI: „Pismo wyrosło w żywym podmiocie wędrującego narodu i z niego, i nadal w nim żyje. [...] Lud Boży - Kościół - jest żywym podmiotem Pisma; w nim słowa Biblii są zawsze teraźniejsze"83. Prawdziwe, duchowe zrozumienie Pisma dokonuje się nie tylko dzięki rzetelnemu warsztatowi filologicznemu, ale przede wszystkim dzięki wspólnocie Kościoła, w której obecny jest Chrystus.

\section{Bibliografia}

\section{Źródła:}

Erasmus, D., Opus epistolarum Des. Erasmi Roterdami (ed. P. S. Allen - H. M. Allen) (Oxford: Oxford University Press 1930) VIII.

Baron, A. - Pietras, H. (red.), Dokumenty Soborów Powszechnych. Tekst łaciński i polski (Kraków: Wydawnictwo WAM 2007) IV/1.

Erasmus, D. „Desiderii Erasmi responsio ad Collationes cuiusdam iuvenis gerontodidascali”, Desiderius Erasmus, Collected Works of Erasmus, LXXIII, Controversies (ed. D. L. Drysdall) (Toronto: University of Toronto Press 1993) 135-263.

Pius XII, „Encyklika Divino Afflante Spiritu”, Nowy Testament na tle epoki (red. E. Dąbrowski) (Poznań: Pallottinum 1958) II, 407-427.

Titelmans, F., Collationes quinque super Epistolam ad Romanos beati Pauli Apostoli (Antuerpiae: Apud Guilielmum Vorstermannum 1529).

Titelmans, F., Epistola Apologetica Fratris Francisci Titelmanni Hasselensis pro opere Collationum ad veteris Ecclesiasticae interpretationis Novi Testamenti defensionem aedito, ad Desyderium Erasmum Roterodamum, sacrae Theologiae professorem (Antuerpiae: Guilielme Vorstermannus 1530).

82 Można zauważyć ciekawą analogię między sporem Erazma i Titelmansa, a współczesnymi sporami o interpretację Biblii w kontekście metody historyczno-krytycznej. Najlepsze zwięzłe przedstawienie tego zagadnienia znajduje się przedmowie książki Benedykta XVI - J. Ratzingera, Jezus z Nazaretu, I, Od chrztu w Jordanie do przemienienia (Kraków: Wydawnictwo M 2007) 5-15.

83 Benedykt XVI - Ratzinger, Jezus z Nazaretu, I, 12. 


\section{Opracowania:}

Augustijn, C., Erasmus: His Life, Works, and Influence (Toronto: University of Toronto Press 1991).

Backus, I., Reformation Readings of the Apocalypse. Geneva, Zurich, and Wittenberg (Oxford: Oxford University Press 2000).

Bakker, P. J. J. M. (red.), The Collège de Montaigu at the University of Paris. Aspects of Its Institutional and Intellectual History (14th-18th Century) (History of Universities 22/2 [Special Issue]; Oxford: Oxford University Press 2008).

Benedykt XVI - Ratzinger, J., Jezus z Nazaretu, I, Od chrztu w Jordanie do przemienienia (Kraków: Wydawnictwo M 2007).

Bentley, J. H., „New Testament Scholarship at Louvain in the Early Sixteenth Century”, Studies in Medieval and Renaissance History 2 (1979) 51-79.

Bentley, J. H., Humanists and Holy Writ: New Testament Scholarship in the Renaissance (Princeton, NJ: Princeton University Press 1983).

Bietenholz, P. G. Encounters with a Radical Erasmus. Erasmus' Work as a Source of Radical Thought in Early Modern Europe (Toronto: University of Toronto Press 2009).

de Calmpthout, Ch., François Titelmans de Hasselt. ... Esquisse biographique (Bruxelles: Jules de Meester 1903).

Cameron, E. (ed.), The New Cambridge History of the Bible, III, From 1450 to 1750 (Cambridge: Cambridge University Press 2013).

Camporeale, S. I., Lorenzo Valla. Umanesimo e teologia (Firenze: Istituto Nazionale di Studi sul Rinascimento 1972).

Christ-von Wedel, C., Erasmus of Rotterdam: Advocate of a New Christianity (Toronto: University of Toronto Press 2013).

Cimosa, M. - Buzzetti, C., Guida allo studio della Bibblia latina. Dalla Vetus latina, alla Vulgata, alla Nova Vulgata (Roma: Istituto Patristico Augustinianum 2008).

Coogan, R., Erasmus, Lee and the Correction of the Vulgate. The Shaking of the Foundations, (Genève: Librairie E. Droz 1992).

D'Alatri, M., „Francesco Tittelmans o del lavoro manuale”, Santi e santità nell'Ordine Capucino, I, Il cinque e il Seicento (red. M. D’Alatri) (Roma: Postulazione Generalle dei Cappuccini 1980) I, 7-19.

Delville, J.-P., „L'évolution des Vulgates et la composition de nouvelles versions latines de la Bible au xvie siècle", Biblia. Les Bibles en latin au temps des Réformes (ed. M.-C. Gomez-Géraud) (Paris: Presses de l'Université Paris-Sorbonne 2008) 71-106.

Di Napoli, G., Lorenzo Valla. Filosofia e religione nell'umanesimo italiano (Roma: Edizioni di Storia e Letteratura 1971).

Domański, J., Erazm i filozofia. Studium o koncepcji filozofii Erazma z Rotterdamu (Warszawa: Fundacja Aletheia 22001).

Domański, J., Erasmiana minora. Studia i szkice o pisarstwie filozoficznym i religijnym Erazma z Rotterdamu (Warszawa: Instytut Tomistyczny - Instytut Filologii Klasycznej UW 2017).

Farge, J. K., „Noël Beda and the Defense of the Tradition”, Biblical Humanism and Scholasticism in the Age of Erasmus (ed. E. Rummel) (Leiden: Brill 2008) 143-164.

Flood, J. L., „Martin Luther's Bible Translation in its German and European Context”, The Bible in the Renaissance. Essays on Biblical Commentary and Translation in the Fifteenth and Sixteenth Centuries (ed. R. Griffiths) (Aldershot: Ashgate 2001) 45-70. 
Fois, M., Il pensiero cristiano di Lorenzo Valla: nel quadro storico-culturale del suo ambiente (Roma: Libreria Editrice dell'Università Gregoriana 1969).

Gibson, M., The Bible in the Latin West, (Notre Dame, IN: University of Notre Dame 1993).

Godet, M., La Congrégation de Montaigu (1490-1580) (Paris: Librairie Ancienne Honore Champion 1912).

Hauser, A. J. (ed.), A History of Biblical Interpretation, I, The Ancient Period (Grand Rapids MI: Eerdmans 2003).

Hauser, A. J. - Watson, D. F. (red.), A History of Biblical Interpretation, II, The Medieval Through the Reformation Periods (Grand Rapids, MI, Eerdmans 2009).

Jenkins, A. K. - Preston, P., Biblical Scholarship and the Church: A Sixteenth Century Crisis of Authority (Ashgate: Aldershot 2016).

Lerner, R. E. (ed.), Neue Richtungen in der hoch- und spätmittelalterlichen Bibelexegese (Berlin: Oldenbourg Wissenschaftsverlag 2009).

van Liere, F. A., An Introduction to the Medieval Bible (Cambridge, Cambridge University Press 2014).

Margolin, J. C., „The Epistle to the Romans (Chapter 11) according to Versions and/or Commentaries of Valla, Colet, Lefèvre and Erasmus", The Bible in the Sixteenth Century (ed. D. C. Steinmetz) (Durham, NC: Duke University Press 1990).

Marsden, R. - Matter, E. A. (ed.), New Cambridge History of the Bible, II, From 600 to 1450 (Cambridge: Cambridge University Press 2012).

McDonald, G., Biblical Criticism in Early Modern Europe. Erasmus, the Johannine Comma, and Trinitarian Debate (Cambridge: Cambridge University Press 2016).

Metzger, B. M. - Ehrman, B. D., The Text of the New Testament. Its Transmission, Corruption, and Restoration (Oxford: Oxford University Press 2005).

Monfasani, J., „Criticism of Biblical Humanists in Quattrocento Italy”, Biblical Humanism and Scholasticism in the Age of Erasmus (ed. E. Rummel) (Leiden: Brill 2008) 15-38.

O’Malley, J. W., Trydent. Co się zdarzyło podczas soboru (Kraków: Wydawnictwo WAM 2014).

Paquay, A., Frans Tittelmans van Hasselt (Franciscus Titelmannus Hassellensis, december 1502-12 september 1537). Opzoekingen over zijn leven, zijne werken en zijne familie (Hasselt: Ceysens 1906).

Post, R. R., The Modern Devotion: Confrontation with Reformation and Humanism (Leiden: E. J. Brill 1968).

Renaudet, A., Humanisme et Renaissance: Dante, Pétrarque, Standonck, Érasme, Lefèvre d'Étaples, Marguerite de Navarre, Rabelais, Guichardin, Giordano Bruno (Genève: Librairie E. Droz 1958).

Rice, E. F., Saint Jerome in the Renaissance (Baltimore: The Johns Hopkins University Press 1985).

Rummel, E., Erasmus'Annotations on the New Testament. From Philologist to Theologian (Toronto: University of Toronto Press 1986).

Rummel, E., Erasmus and his Catholic Critics (Nieuwkoop: Graaf 1989) I-II.

Rummel, E., The Humanist-Scholastic Debate in the Renaissance \& Reformation, (Cambridge, Mass., Harvard University Press 1998.

Rummel, E., The Confessionalization of Humanism in Reformation Germany (Oxford: Oxford University Press 2000).

Griffiths, R. (ed.), The Bible in the Renaissance. Essays on Biblical Commentary and Translation in the Fifteenth and the Sixteenth Centuries (Aldershot: Ashgate 2001).

Rummel, E. (ed.), Biblical Humanism and Scholasticism in the Age of Erasmus (Leiden: Brill 2008). 
Sartori, P., „La Controversia Neotestamentaria Tra Frans Titelmans ed Erasmi da Roterdam (1527-1530 CA.): Liniee di Sviluppo e Contenuti”, Humanistica Lovaniensia 52 (2003) 77-135. Sartori, P., „Tracce dell'opera di Jacobus Latomus nel «Prologus Apologeticus» di Frans Titelmans”, Margarita amicorum. Studi di cultura europea per Agostino Sottili (ed. F. Forner - C. M. Monti - P. G. Schmidt) (Milano: Vita \& Pensiero 2005) 1032-1042.

Sartori, P., „Frans Titelmans, the Congregation of Montaigu, and Biblical Scholarship”, Biblical Humanism and Scholasticism in the Age of Erasmus (ed. E. Rummel) (Leiden: Brill 2008) 215-223.

Schmitt, C. B., „The Rise of the Philosophical Textbook”, The Cambridge History of Renaissance Philosophy (ed. C. B. Schmitt et al.) (Cambridge: Cambridge University Press 2009).

Schönau, C., Jacques Lefèvre d'Etaples und die Reformation (Gütersloh: Gtersloher Verlagshaus 2017). Smalley, B., The Study of the Bible in the Middle Ages (Notre Dame, IN, University of Notre Dame Press 1964).

Steinmetz, D. C. (ed.), The Bible in the Sixteenth Century (Durham, NC: Duke University Press 1990). de Troeyer, B., Bio-bibliographia Franciscana Neerlandica saeculi XVI (Nieuwkoop: B. de Graaf 1969) I. 